\title{
TNF combined with IFN- $\alpha$ accelerates NF-кB-mediated apoptosis through enhancement of Fas expression in colon cancer cells
}

\author{
M Kimura ${ }^{1}$, M Haisa*,1, H Uetsuka ${ }^{1}$, M Takaoka ${ }^{1}$, T Ohkawa ${ }^{1}$, \\ R Kawashima', T Yamatsuji ${ }^{1}$, M Gunduz ${ }^{2}$, Y Kaneda ${ }^{3}$, N Tanaka ${ }^{1}$ \\ and $Y$ Naomoto ${ }^{1}$ \\ ${ }^{1}$ First Department of Surgery, Graduate School of Medicine and Dentistry, \\ Okayama University, Okayama, Japan \\ 2 Department of Oral Pathology and Medicine, Graduate School of Medicine and \\ Dentistry, Okayama University, Okayama, Japan \\ 3 Division of Gene Therapy Science, Osaka University Medical School, Osaka, \\ Japan \\ * Corresponding author: M Haisa, First Department of Surgery, Graduate \\ School of Medicine and Dentistry, Okayama University, 2-5-1 Shikatacho, \\ Okayama 700-8558, Japan. Tel: +81-86-235 7257; Fax: +81-86-221 8775; \\ E-mail: mhaisa@cc.okayama-u.ac.jp
}

Received 13.6.02; revised 20.10.02; accepted 29.10.02 Edited by Miura

\begin{abstract}
Immunostaining and EMSA revealed that NF- $\kappa \mathrm{B}$ was activated strongly by TNF/IFN- $\alpha$ compared to TNF alone in a human colon adenocarcinoma cell line, RPMI4788. Although inhibition of activated NF- $\kappa \mathrm{B}$, by using an NF- $\kappa \mathrm{B}$ decoy, reduced cell viability after treatment with TNF only, NF- $\kappa B$ decoy resulted in recovery of cell viability after TNF/IFN- $\alpha$ treatment. Caspase-3 activity was increased in cells induced by TNF/IFN$\alpha$, while suppression of caspase-3 activity was observed in cells transfected with NF- $\kappa \mathrm{B}$ decoy and then treated by TNF/ IFN- $\alpha$. On the other hand, Fas expression was strongly enhanced by TNF/IFN- $\alpha$, and inhibition of TNF/IFN- $\alpha$-induced NF- $\kappa$ B activation, by using NF- $\kappa$ B decoy, decreased Fas expression. Cell viability and caspase- 3 activity decreased in cells treated with TNF/IFN- $\alpha$ and anti-FasL antibody. Taken together, our findings suggest that activated NF- $\kappa B$ induced by the crosstalk between TNF and IFN- $\alpha$ is a novel proapoptotic signal acting via enhancement of Fas expression. Cell Death and Differentiation (2003) 10, 718-728. doi:10.1038/ sj.cdd. 4401219
\end{abstract}

Keywords: NF- $\kappa \mathrm{B}$; IFN- $\alpha$; TNF; colon cancer; apoptosis; Fas

Abbreviations: AFC, 7-amino-4-trifluoromethyl coumarin; DEVD, Asp-Glu-Val-Asp; EMSA, electrophoretic mobility shift assay; FADD, Fas-associated death domain protein; FasL, Fas ligand; HU, house unit; HVJ, hemagglutinating virus of Japan; IFN- $\alpha$, interferon- $\alpha$; IKK, I $\kappa$ B kinase; IU, international unit; I $\kappa \mathrm{B}$, inhibitor of $\mathrm{NF}-\kappa \mathrm{B}$; iNOS, inducible nitric-oxide synthase; LPS, lipopolysaccharide; NF- $\kappa \mathrm{B}$, nuclear factor-kappa B; NIK, NF- $\kappa$ Binducing kinase; $\mathrm{NO}$, nitric oxide; ODN, oligodeoxynucleotide; PARP, poly (ADP-ribose) polymerase; PKR, double-stranded
RNA-activated protein kinase; RIP, receptor-interacting protein; TNF, tumor necrosis factor; TNF/IFN- $\alpha$, combined treatment with TNF and IFN- $\alpha$; TNFR, tumor necrosis factor receptor; TRADD, TNFR1-associated death domain protein; TRAF2, TNF receptorassociated factor 2; YY1, Yin Yang ${ }^{-1}$.

\section{Introduction}

Tumor necrosis factor (TNF) is a proinflammatory cytokine with many biological activities including cytostatic and cytotoxic effects, differentiation, and proliferation in various tumor cells. ${ }^{1,2}$ These biological properties are mediated via two distinct cell surface receptors, tumor necrosis factor receptor 1 (TNFR1) and TNFR2.,4 The majority of known TNF activities have been attributed to TNFR1. Direct signaling through TNFR2 occurs less extensively, and appears to be mainly confined to cells of the immune system. TNF initiates its signaling by binding to and trimerizing TNFR1. TNFR1 interacts directly with its signal transducer, TNFR1-associated death domain protein (TRADD), which is involved in activating two distinct pathways including apoptosis and nuclear factor-kappa B (NF- $\kappa \mathrm{B})$ transactivation. ${ }^{5}$ To induce apoptosis, TRADD interacts with Fas-associated death domain protein (FADD), which consequently activates procaspase-8 that leads to the progress of the caspase cascade. $^{6,7}$ TRADD also interacts with TNF receptor-associated factor 2 (TRAF2) and receptor-interacting protein (RIP) to activate $\mathrm{NF}-\kappa \mathrm{B}$. This interaction phosphorylates and activates NF- $\kappa$ B-inducing kinase (NIK). ${ }^{8}$ The inhibitor of NF$\kappa \mathrm{B}(\mathrm{I} \kappa \mathrm{B})$ kinase $(\mathrm{IKK})$ complex $^{9}$, composed of $\mathrm{IKK} \alpha^{10}$ and $\operatorname{IKK} \beta^{11}$, is phosphorylated by the activated form of NIK. NIKinduced activated IKK phosphorylates $I_{\kappa} \mathrm{B},{ }^{12}$ which inhibits translocation of NF- $\kappa \mathrm{B}$, at specific serine residues (serine 32 and 36 in $\mathrm{I} \kappa \mathrm{B} \alpha$, serine 19 and 23 in $\mathrm{I} \kappa \mathrm{B} \beta) .{ }^{12-15}$ Phosphorylation of $\mathrm{I} \kappa \mathrm{B}$ at specific serine residues initiates the ubiquitination of $I_{\kappa} \mathrm{B}$ and recognition by the $26 \mathrm{~S}$ proteasome. ${ }^{16,17} \mathrm{NF}-\kappa \mathrm{B}$ is released after $I_{\kappa} \mathrm{B}$ is degraded and promptly translocates to the nucleus, binds to the $\kappa \mathrm{B}$ site on DNA, and initiates transcription of target genes, including Fas, FasL, C-myc, and $\mathrm{I} \kappa \mathrm{B} \alpha$.

The antitumor effect of TNF is enhanced by interferons (IFNs). ${ }^{2,18}$ Recently, we reported that TNF/IFN- $\alpha$ combined treatment inhibited the in vitro and in vivo proliferation of human colon adenocarcinoma cells. ${ }^{19,20}$ Previous reports demonstrated that TNF-activated NF- $\kappa \mathrm{B}$ has an antiapoptotic effect. $^{21-25}$ Beg et al. $^{21}$ showed that TNF treatment of fibroblasts and macrophages from RelA-deficient $\left(\mathrm{ReIA}^{-1-}\right)$ mice resulted in a significant reduction in viability, whereas $\mathrm{ReIA}^{+/+}$cells were unaffected. In addition, they demonstrated that reintroduction of RelA into RelA ${ }^{-/-}$fibroblasts resulted in enhanced survival. ${ }^{21}$ Other investigators demonstrated that 
TNF-induced antitumor effects were enhanced by inhibition of $\mathrm{NF}-\kappa \mathrm{B}$ activation by transfecting the dominant-negative mutant $\mathrm{l}_{\kappa} \mathrm{B} \alpha$, which was not phosphorylated at specific serine residues and not dissociated from $\mathrm{NF}-\kappa \mathrm{B}$, into human fibrosarcoma cells, human embryo fibroblasts, and rat mesangial cells. ${ }^{22-24}$ Otsuka et al. ${ }^{25}$ also reported that introduction of dominant-negative $\mathrm{NF}-\kappa \mathrm{B}$ into malignant glioma cells, together with TNF, augmented sensitivity to TNF and resulted in a significant decrease in cell number, and that cell cycle analysis revealed this growth inhibition was because of impairment of cell cycle progression. Therefore, we hypothesized that TNF/IFN- $\alpha$ prevented NF- $\kappa$ B activation, and investigated whether apoptosis and NF- $\kappa \mathrm{B}$ activation were altered when cells were treated with TNF/IFN- $\alpha$.

Recent studies demonstrated that the transcriptional activities of DNA-binding proteins could be inhibited by double-stranded oligodeoxynucleotides (ODNs) that compete for binding to their specific target sequences in promoters and enhancers. $^{26-28}$ The NF- $\kappa$ B decoy ODN, which comprised $20 \mathrm{bp}$ of double-stranded ODN with high affinity for $\mathrm{NF}-\kappa \mathrm{B}$, inhibited binding of NF- $\kappa$ B to DNA by competitively binding to the $\kappa \mathrm{B}$ site and blocking transcription of target genes. ${ }^{27,28}$ Thus, we used this decoy to inhibit NF- $\kappa$ B activation, and examined whether cell viability was altered by this inhibition in tumor cells treated with TNF/IFN- $\alpha$. Although nonviral gene transfer vectors, for example lipofection methods, have been developed as therapeutic or research strategies, their main limitation has been low efficiency of gene expression. To overcome this problem, Kaneda et al. ${ }^{29,30}$ produced a new class of transfection vehicles, hemagglutinating virus of Japan (HVJ)-liposomes. This vector is several times more efficient in transfection than conventional vehicles. Thus, we used HVJliposomes as transfer vectors to efficiently transfect the NF- $\kappa$ B decoy into tumor cells.

Recently, Ouaaz et al. ${ }^{31}$ reported that combined TNF and IFN- $\gamma$ treatment upregulated Fas mRNA expression in mouse fibroblasts. Moreover, recent studies have demonstrated an $\mathrm{NF}-\kappa \mathrm{B}$ binding site on the human Fas promoter. ${ }^{32}$ Thus, we also tested whether TNF/IFN- $\alpha$ altered Fas expression.

In the present study, we investigated the relation between $\mathrm{NF}-\kappa \mathrm{B}$ activation and apoptosis in tumor cells treated with TNF/IFN- $\alpha$. Our results showed that NF- $\kappa$ B activation induced by TNF/IFN- $\alpha$ is a novel proapoptotic signaling pathway acting via enhancement of Fas expression.

\section{Results}

\section{TNF/IFN- $\alpha$ inhibited cell growth}

We first confirmed the viability of RPMI4788 cells treated with each cytokine alone. RPMI4788 cells were seeded onto sixwell plates at $10^{5}$ cells/well. After preculture for $48 \mathrm{~h}$, cells were treated with cytokines for 24,48 , and $72 \mathrm{~h}$ as indicated and then harvested. Viable cells were counted by trypan blue exclusion, and relative viability was calculated. As shown in Figure 1, treatment of RPMI4788 cells with TNF/IFN- $\alpha$ markedly reduced their viability. After $72 \mathrm{~h}$ of TNF/IFN- $\alpha$ cotreatment $\left(10^{4} \mathrm{HU} / \mathrm{ml}\right)$, cell growth was strongly inhibited (35.4\% (TNF/IFN- $\alpha$ ) versus $75.3 \%$ (IFN- $\alpha$ alone) and $77.1 \%$
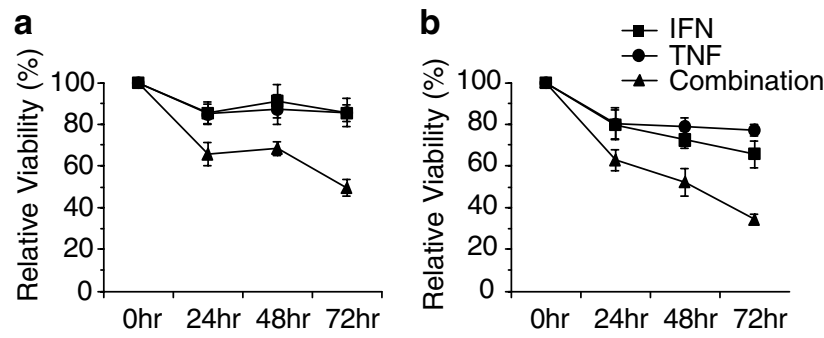

Figure $1 \mathrm{TNF} / \mathrm{FN}-\alpha$ exhibited additive cytotoxicity. Cells were seeded onto sixwell plates at $10^{5} \mathrm{cells} /$ well, precultured for $48 \mathrm{~h}$, and treated with or without each cytokine. After treatment for 24,48 , or $72 \mathrm{~h}$, cells were harvested and viable cell numbers were counted by trypan blue exclusion. Relative viability was calculated as follows: relative viability $(\%)=($ viable cell numbers in treated group/viable cell numbers in control group) $\times 100$. (a) Treatment with IFN- $\alpha 10^{3} \mathrm{IU} / \mathrm{ml}$, TNF $1.4 \mathrm{ng} / \mathrm{ml}$, combination $10^{3} \mathrm{HU} / \mathrm{ml}$; (b) Treatment with IFN- $\alpha 10^{4} \mathrm{IU} / \mathrm{ml}$, TNF $14 \mathrm{ng} / \mathrm{ml}$, TNF/IFN- $\alpha$ combination $10^{4} \mathrm{HU} / \mathrm{ml}\left(10^{4} \mathrm{IU} / \mathrm{ml}\right.$ of $\mathrm{IFN}-\alpha+14 \mathrm{ng} / \mathrm{ml}$ of TNF); $\mathbf{\square}$ IFN- $\alpha$;, TNF; $\boldsymbol{\Delta}$, combination. Data from three independent experiments involving triplicate assays were averaged and are presented as mean \pm S.D

(TNF alone)). These findings suggest that TNF/IFN- $\alpha$ may have an additive antitumor effect.

\section{TNF/IFN- $\alpha$ enhanced apoptosis}

Treatment with IFN- $\alpha$ or TNF alone, or TNF/IFN- $\alpha$ cotreatment, exerted an anticellular effect on RPMI 4788 cells. TNF is cytotoxic to tumor cell lines, because of induction of apoptosis. ${ }^{5,6,21-23}$ We therefore investigated whether TNF/ IFN- $\alpha$ would induce apoptosis of RPMI4788 cells. After treatment with each cytokine for 24,48 , and $72 \mathrm{~h}$ as indicated, cells were harvested, and whole-cell extracts were prepared as described in Materials and Methods. Cleavage of poly (ADP-ribose) polymerase (PARP) was analyzed by Western blot analysis using $40 \mu \mathrm{g}$ of whole-cell extracts to investigate the possible induction of apoptosis. As shown in Figure 2, TNF/IFN- $\alpha$ cotreatment for $24 \mathrm{~h}$ was associated with low-level cleavage of PARP, and this cleavage increased significantly in a time-dependent manner. In contrast, little PARP cleavage was induced by IFN- $\alpha$ or TNF treatment alone. These data suggested that TNF/IFN- $\alpha$ strongly induced apoptosis of RPMI4788 cells.

\section{TNF/IFN- $\alpha$ activated NF- $\kappa$ B}

We demonstrated that TNF/IFN- $\alpha$ cotreatment significantly reduced viability of RPMI4788 cells because of enhanced apoptosis. TNF induces both apoptosis and NF- $\kappa$ B activation; the latter effect serves an antiapoptotic function in tumor cells. $^{21-25}$ Thus, we hypothesized that NF- $\kappa$ B activation may be inhibited by TNF/IFN- $\alpha$, and that growth of RPMI4788 cells might be prevented by this inhibition. We therefore investigated whether NF- $\kappa \mathrm{B}$ activation was altered in RPMI4788 cells treated with TNF/IFN- $\alpha$. First, we studied the nuclear translocation of NF- $\kappa$ B in RPMI4788 by immunohistochemistry. Cells were treated with or without IFN- $\alpha\left(10^{2}-10^{5} \mathrm{IU} / \mathrm{ml}\right)$, TNF $(0.14-140 \mathrm{ng} / \mathrm{ml})$, or TNF/IFN- $\alpha\left(10^{2}-10^{5} \mathrm{HU} / \mathrm{ml}\right)$ for 5$90 \mathrm{~min}$, and immunohistochemistry was performed as described in Materials and Methods. Examples of NF- $\kappa \mathrm{B}$ staining are shown in Figure $3 a$ and $b$. Cells with staining 


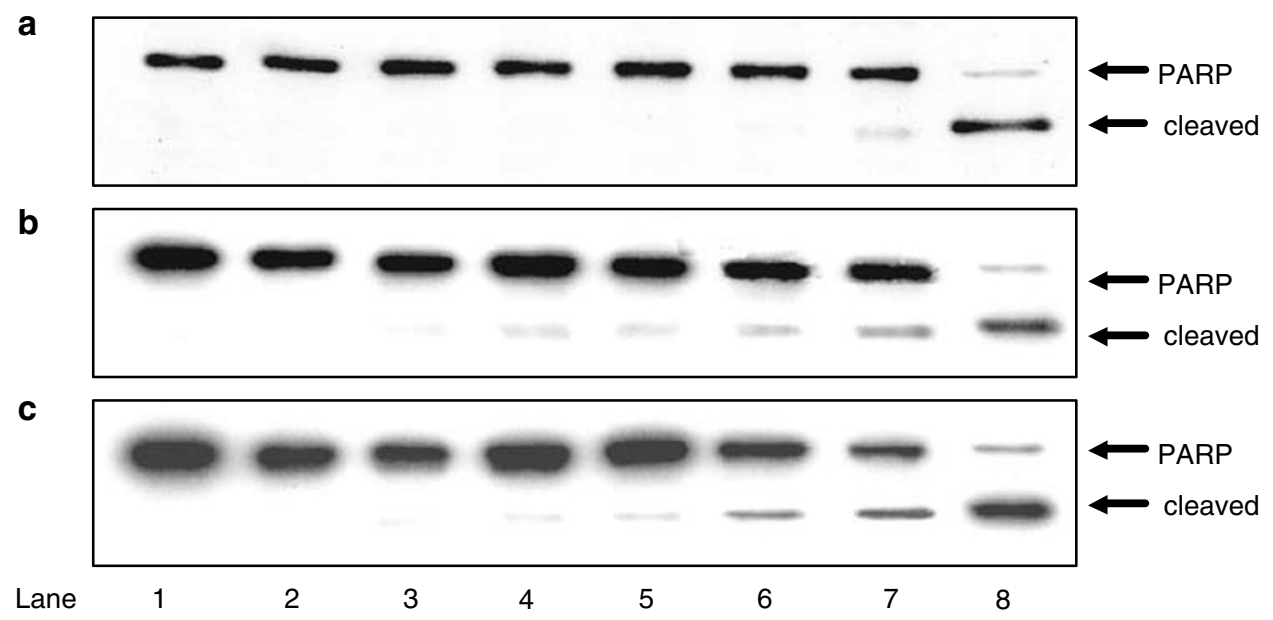

Figure 2 TNF/IFN- $\alpha$ strongly induced apoptosis. Cells were treated with or without each cytokine for 24,48 , or $72 \mathrm{~h}$, and then harvested and lysed as described in Materials and Methods. Equivalent amounts of whole-cell extracts were analyzed for cleavage of PARP by Western blot using anti-PARP antibody as described in Materials and Methods. (a) Treatment for $24 \mathrm{~h}$; (b) $48 \mathrm{~h}$; (c) $72 \mathrm{~h}$. Arrows indicate cleaved PARP. Lanes 1, control; 2, IFN- $\alpha 10^{3} \mathrm{IU} / \mathrm{ml} ; 3$, IFN- $\alpha 10^{4} \mathrm{IU} / \mathrm{ml} ; 4$, TNF $1.4 \mathrm{ng} /$ $\mathrm{ml} ; 5$, TNF $14 \mathrm{ng} / \mathrm{ml} ; 6$, TNF/IFN- $\alpha$ combination $10^{3} \mathrm{HU} / \mathrm{ml}\left(10^{3} \mathrm{IU} / \mathrm{ml}\right.$ of IFN- $\alpha+1.4 \mathrm{ng} / \mathrm{ml}$ of TNF); 7 , TNF/IFN- $\alpha$ combination $10^{4} \mathrm{HU} / \mathrm{ml}\left(10^{4} \mathrm{IU} / \mathrm{ml}\right.$ of IFN- $\alpha+14 \mathrm{ng} / \mathrm{ml}$ of TNF); 8 , positive control. Similar findings were obtained in two other independent experiments

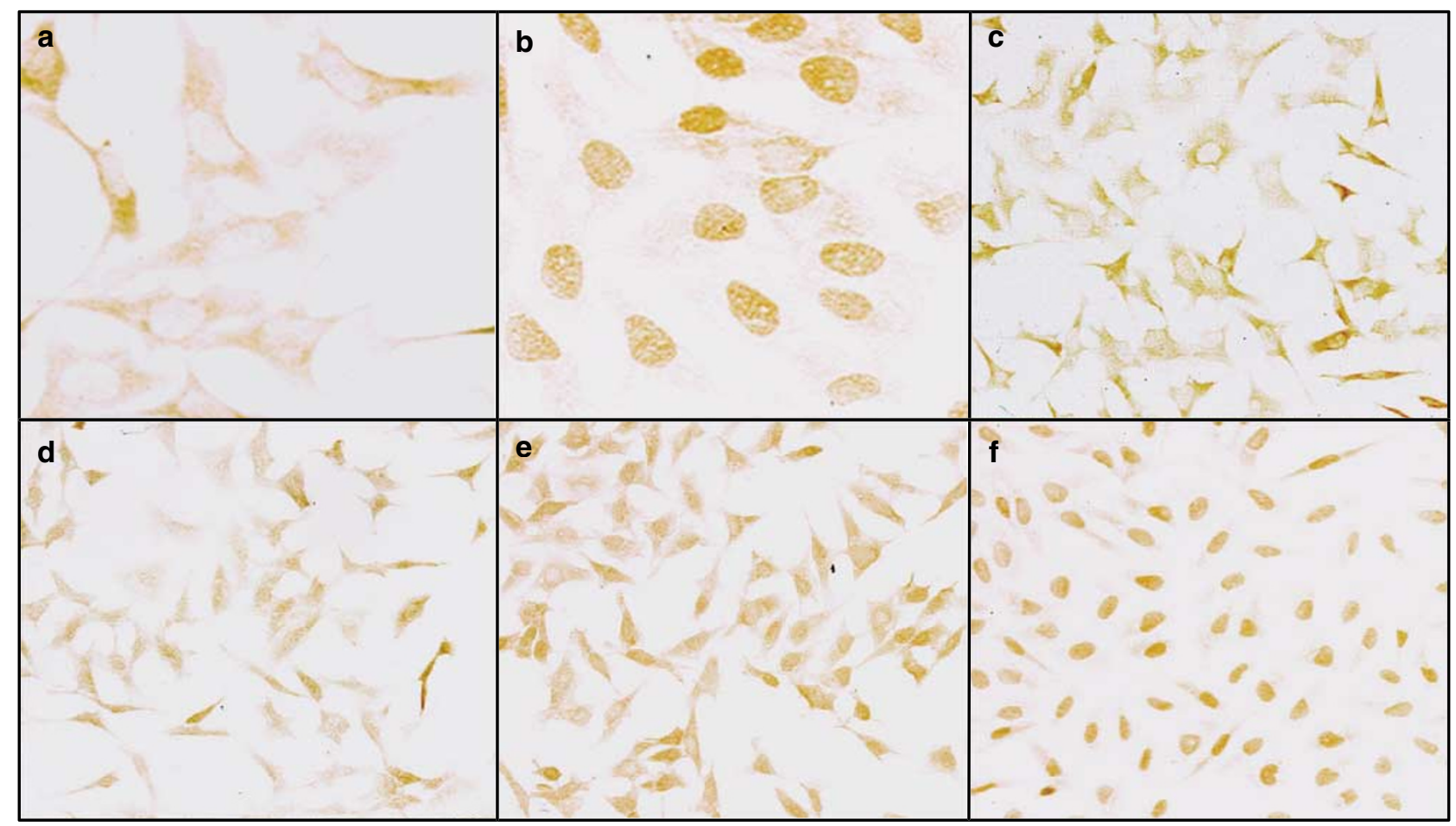

Figure 3 Nuclear translocation of NF- $\kappa$ B in RPMI4788 cells. Cells $\left(5 \times 10^{4}\right)$ were seeded onto a chamber slide, precultured for $48 \mathrm{~h}$, and then treated with or without each cytokine. Treated cells were subjected to immunohistochemical staining as described in Materials and Methods. Examples of NF- $\kappa B$ staining are shown in (a) (b). (a) Nuclei negatively stained for NF- $\kappa$ B; (b) nuclei positively stained for NF- $\kappa$ B. Results of staining of cells treated for 15 min are shown in (c-f), (c) control; (d) IFN- $\alpha$ $10^{4} \mathrm{IU} / \mathrm{ml}$ treatment; (e) TNF $14 \mathrm{ng} / \mathrm{ml}$ treatment; (f), TNF/FN- $\alpha$ combination $10^{4} \mathrm{HU} / \mathrm{ml}\left(10^{4} \mathrm{IU} / \mathrm{ml}\right.$ of IFN- $\alpha+14 \mathrm{ng} / \mathrm{ml}$ of TNF) treatment

restricted to the cytoplasm were designated as negative for nuclear translocation of NF- $\kappa$ B (Figure $3 a$ ), while cells with strong nuclear staining, with or without minor cytoplasmic staining, were designated as positive (Figure 3b). Results of immunohistochemical staining of cells treated or untreated with cytokines for $15 \mathrm{~min}$ are shown in Figure $3 \mathrm{c}-\mathrm{f}$. The control group was negative for nuclear translocation of NF- $\kappa B$ as only the cytoplasm was stained (Figure 3c). Cells treated with $10^{4} \mathrm{IU} / \mathrm{ml} \mathrm{IFN}-\alpha$ were also negative for nuclear translocation of $\mathrm{NF}-\kappa \mathrm{B}$ by exhibiting strong cytoplasmic staining with only slight nuclear positivity compared to the controls (Figure $3 d$ ). TNF $(14 \mathrm{ng} / \mathrm{ml})$ stimulation conferred strong nuclear staining 
a

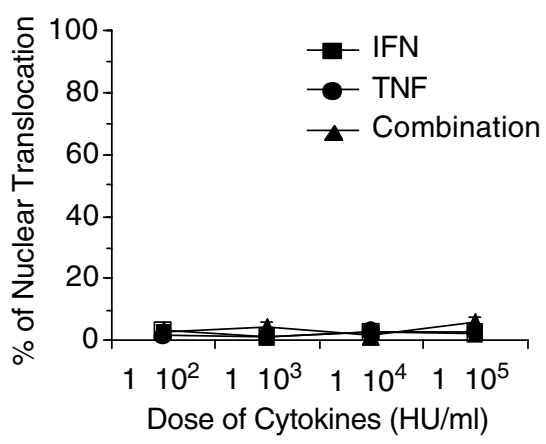

b

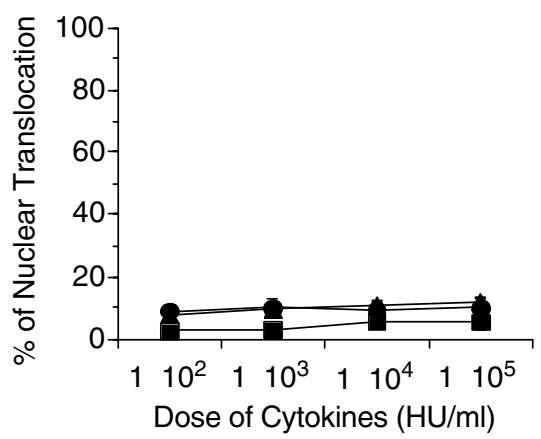

C

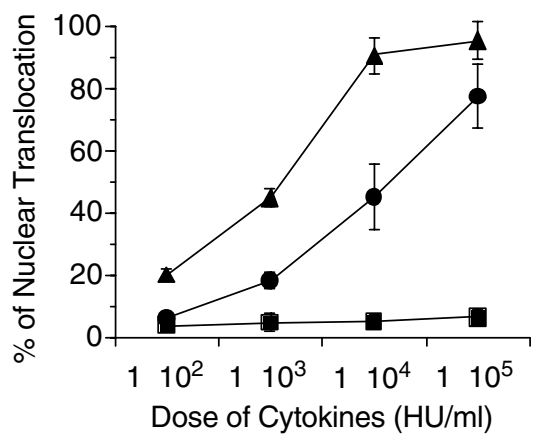

d

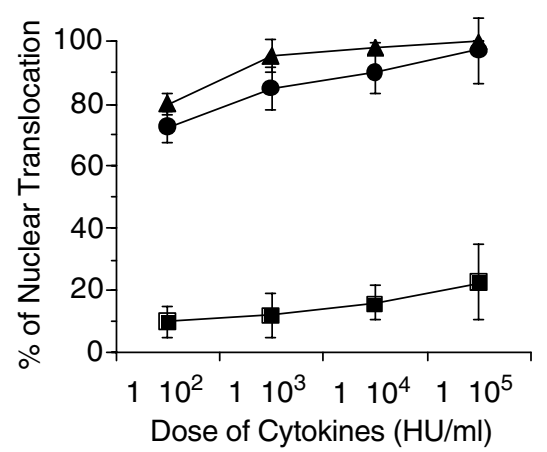

e

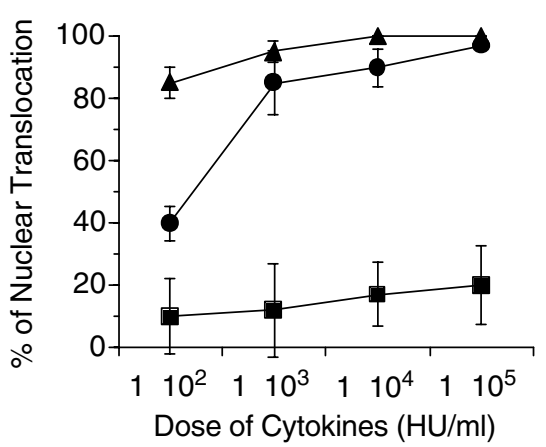

f

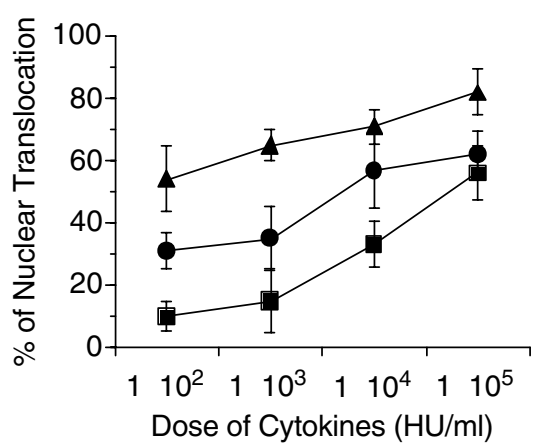

Figure 4 Ratios of nuclear translocation of NF- $\kappa$ B in RPMI 4788 cells. Cells $\left(5 \times 10^{4}\right)$ were precultured as described in Figure 3 and then treated for $5-90$ min with or without each cytokine. Treated cells were subjected to immunohistochemical staining, and the percentage of positively stained nuclei was semiquantitatively evaluated by counting at least 2000 cells/slide as follows: ratio of nuclei positively stained cells $(\%)=($ number of nuclei positively stained cells/total cells counted) $\times 100$. (a) Treatment for $5 \mathrm{~min}$, (b) $10 \mathrm{~min}$, (c) $15 \mathrm{~min}$, (d) $30 \mathrm{~min}$, (e) $60 \mathrm{~min}$, (f) $90 \mathrm{~min}$. $\mathbf{\square}$, IFN- $\alpha$; $\boldsymbol{\bullet}$, TNF; $\boldsymbol{\Delta}$, combination. Data from three independent experiments were averaged and presented as mean \pm S.D

in the cells, which were designated as positive for nuclear translocation of NF- $\kappa \mathrm{B}$ (Figure $3 \mathrm{e}$ ). Contrary to our predictions, cells treated with TNF/IFN- $\alpha\left(10^{4} \mathrm{HU} / \mathrm{ml}\right)$ exhibited very strong nuclear staining, and were thus positive for $\mathrm{NF}-\kappa \mathrm{B}$ nuclear translocation (Figure $3 \mathrm{f}$ ). Ratios of NF- $\kappa \mathrm{B}$ nuclear translocation in RPMI4788 cells with or without treatment of each cytokine for 5-90 min are shown in Figure 4. NF- $\kappa$ B was most strongly translocated to nuclei by TNF/IFN- $\alpha$ combination for all treatment durations. In addition, NF- $\kappa$ B translocation induced by TNF/IFN- $\alpha$ occurred early, by $10-15 \mathrm{~min}$, which differed from translocation induced by TNF treatment alone in the early phase. NF- $\kappa \mathrm{B}$ nuclear translocation was strongest after TNF/IFN- $\alpha$ treatment for 30-60 min, and continued until $90 \mathrm{~min}$; the duration of nuclear translocation of $N F-\kappa B$ induced by TNF/IFN- $\alpha$ combined treatment exceeded that induced by TNF alone.

We then investigated whether activation of $\mathrm{NF}-\kappa \mathrm{B}$ detected by immunohistochemical analysis actually correlated with NF$\kappa \mathrm{B}$ binding to DNA, as detected by electrophoretic mobility shift assay (EMSA). Following treatment of cells with or without each cytokine (IFN- $\alpha 10^{4} \mathrm{IU} / \mathrm{ml}$, TNF $14 \mathrm{ng} / \mathrm{ml}$, combination $10^{4} \mathrm{HU} / \mathrm{ml}$ ) for $10-120 \mathrm{~min}$, nuclear extracts were prepared as described in Materials and Methods, and NF $-\kappa$ B activation was then analyzed using EMSA. As shown in Figure 5, consistent with the immunohistochemical analysis, TNF/IFN $-\alpha$ induced the strongest NF- $\kappa$ B DNA binding activity; the duration of NF- $\kappa$ B activation was also longest after TNF/IFN- $\alpha$ cotreatment. Taken together, these results suggested that TNF/IFN- $\alpha$ activated NF- $\kappa$ B more strongly in the early phase and that this activation continued for a longer duration, compared to TNF alone.

\section{Inhibition of NF- $\kappa \mathrm{B}$ activation recovered cell viability after TNF/IFN- $\alpha$ cotreatment}

Contrary to our expectation, TNF/IFN- $\alpha$ activated NF- $\kappa$ B most strongly, although this combination was also the most potent inducer of apoptosis. Whether the activated NF- $\kappa$ B induced by TNF/IFN- $\alpha$ was antiapoptotic was not clear, although TNFinduced NF- $\kappa$ B was known to be antiapoptotic. In the next step, we therefore examined the relation between $N F-\kappa B$ activation induced by TNF/IFN- $\alpha$ and apoptosis, by determining whether an NF- $\kappa$ B decoy could alter cell viability by inhibiting NF- $\kappa \mathrm{B}$ activation. The NF- $\kappa \mathrm{B}$ decoy comprised ODNs that block the binding of NF- $\kappa \mathrm{B}$ to promoter regions of targeted genes by competitively binding to the $\kappa \mathrm{B}$ site, resulting in inhibition of gene activation in vivo. Therefore, target gene transcription should be blocked by NF- $\kappa \mathrm{B}$ decoy, but nuclear translocation should be unaffected if the action of the ODN is to block DNA binding. To confirm this hypothesis, nuclear translocation was examined in cells induced via TNF/ 
with or without cytokines, are shown in Figure 8a. No difference in cell viability was detected in the control or IFNtreated cells when the NF- $\kappa \mathrm{B}$ decoy or scramble decoy was added. In contrast, TNF treatment combined with the NF- $\kappa \mathrm{B}$ decoy reduced cell viability, whereas the scramble decoy alone had no effect. These findings are consistent with TNFinduced activation of NF- $\kappa \mathrm{B}$ functioning in an antiapoptotic manner. The NF- $\kappa \mathrm{B}$ decoy resulted in improved cell viability by about $25 \%$ after TNF/IFN- $\alpha$ cotreatment, whereas the scramble decoy had no influence. We then investigated whether the recovery of cell viability by inhibiting NF- $\kappa$ B activation in cells treated with TNF/IFN- $\alpha$ was because of reduction of apoptosis. Cells were seeded onto six-well plates at $10^{5} \mathrm{cells} /$ well and precultured for $48 \mathrm{~h}$. After transfecting with or without NF- $\kappa$ B decoy, cells were treated with or without TNF/IFN- $\alpha\left(10^{4} \mathrm{HU} / \mathrm{ml}\right)$, lysed, and caspase-3 activity was measured as described in Materials and Methods. As shown in Figure $8 \mathrm{~b}$, strong caspase-3 activity was detected in cells treated with the TNF/IFN- $\alpha$ combination, while caspase- 3 activity was reduced by about $40 \%$ when cells were treated with both TNF/IFN- $\alpha$ combination and NF- $\kappa \mathrm{B}$ decoy. These findings suggest that the NF- $\kappa \mathrm{B}$ activation induced by TNF/ IFN- $\alpha$ was proapoptotic in RPMI4788 cells, whereas in contrast, TNF-induced NF- $\kappa$ B was antiapoptotic.

\section{TNF/IFN- $\alpha$ enhanced Fas expression}

Figure 5 NF- $\kappa$ B activation in RPMI 4788 cells. Cells $\left(1 \times 10^{7}\right)$ were treated with or without each cytokine (IFN- $\alpha 10^{4} \mathrm{IU} / \mathrm{ml}$, TNF $14 \mathrm{ng} / \mathrm{ml}$, combination $10^{4} \mathrm{HU} / \mathrm{ml}$ $\left(10^{4} \mathrm{IU} / \mathrm{ml}\right.$ of IFN- $\alpha+14 \mathrm{ng} / \mathrm{ml}$ of TNF)) for the indicated times, and then harvested and lysed as described in Materials and Methods. Equal amounts of nuclear extracts were subjected to EMSA with a ${ }^{32} \mathrm{P}$-labeled oligodeoxynucleotide probe containing the NF- $\kappa$ B DNA-binding site. (a) Treatment for 10, 15, $30 \mathrm{~min}$; (b) treatment for $60,90,120 \mathrm{~min}$. Arrows indicate NF- $\kappa \mathrm{B}$. Similar findings were obtained in three other independent experiments

IFN- $\alpha$ and treated with or without NF- $\kappa$ B decoy. As shown in Figure 6, neither NF- $\kappa$ B nor the scramble decoy affected NF$\kappa \mathrm{B}$ translocation.

We then tested whether the NF- $\kappa$ B decoy could block NF- $\kappa$ B activation in our experimental model. Cells were seeded into $75 \mathrm{~cm}^{2}$ flasks at $10^{6} \mathrm{cells} / \mathrm{flask}$, precultured for $48 \mathrm{~h}$, and then transfected with either NF- $\kappa \mathrm{B}$ decoy $(20$ or $40 \mu \mathrm{g} / \mathrm{ml}$ ) or scramble decoy $(40 \mu \mathrm{g} / \mathrm{ml})$ as described in Materials and Methods. The cells were then treated with TNF/IFN- $\alpha$ combination $\left(10^{4} \mathrm{HU} / \mathrm{ml}\right)$ for $15 \mathrm{~min}$, and nuclear extracts were prepared. NF- $\kappa$ B activation was then analyzed using EMSA. As shown in Figure 7 , although NF- $\kappa$ B activation was strong in cells without decoy treatment, transfection of NF- $\kappa$ B decoy (20 or $40 \mu \mathrm{g} / \mathrm{ml}$ ) blocked NF- $\kappa$ B activation, and scramble decoy did not affect NF- $\kappa \mathrm{B}$ activation by TNF/IFN- $\alpha$ cotreatment. Therefore, we concluded that $20 \mu \mathrm{g} / \mathrm{ml}$ of $\mathrm{NF}-\kappa \mathrm{B}$ decoy efficiently inhibited NF- $\kappa$ B activation by TNF/IFN- $\alpha$ cotreatment.

Next, we examined whether inhibition of TNF/IFN- $\alpha-$ induced NF- $\kappa \mathrm{B}$ activation by the NF- $\kappa \mathrm{B}$ decoy affected cell viability. RPMI4788 cells were seeded onto six-well plates, and transfected with either NF- $\kappa$ B decoy or a scramble decoy as described in Materials and Methods, after preculture for $48 \mathrm{~h}$. We then treated the cells for $48 \mathrm{~h}$ with or without each cytokine as indicated, and viability was examined by trypan blue exclusion. Relative viabilities of RPMI4788 cells, treated

Ouaaz et al. ${ }^{31}$. reported that combined TNF and IFN- $\gamma$ treatment upregulated Fas mRNA expression in fibroblasts. Moreover, recent studies have revealed an NF- $\kappa$ B binding site on the human Fas promoter. ${ }^{32}$ We therefore investigated whether Fas protein was upregulated when RPMI4788 cells were treated with either cytokine. Cells were treated (or untreated, control) for $48 \mathrm{~h}$ with each cytokine, and then whole cell extracts were prepared as described in Materials and Methods and subjected to immunoblot analysis to investigate Fas expression. As shown in Figure 9a, Fas protein expression was strongly enhanced by $\mathrm{TNF} / \mathrm{IFN}-\alpha$, and also enhanced to a small extent by TNF or IFN- $\alpha$ treatment alone.

We then tested the effect of treatment of RPMI 4788 cells with each cytokine alone, or TNF/IFN- $\alpha$, together with the NF- $\kappa B$ decoy, on Fas protein expression. After transfection of the NF$\kappa \mathrm{B}$ decoy or scramble decoy, cells were treated with or without IFN- $\alpha\left(10^{3}\right.$ or $\left.10^{4} \mathrm{IU} / \mathrm{ml}\right)$, TNF $(1.4$ or $14 \mathrm{ng} / \mathrm{ml})$, or TNF/IFN- $\alpha$ $\left(10^{3}\right.$ or $\left.10^{4} \mathrm{HU} / \mathrm{ml}\right)$ for $48 \mathrm{~h}$, followed by cell lysis and Western blotting for Fas expression. As shown in Figure 9b, addition of the $\mathrm{NF}-\kappa \mathrm{B}$ decoy to inhibit $\mathrm{NF}-\kappa \mathrm{B}$ activation resulted in decreased Fas protein expression in the TNF/IFN- $\alpha$ group, whereas no change was observed after addition of the NF- $\kappa \mathrm{B}$ decoy in cells treated with TNF or IFN- $\alpha$ alone (data not shown). The scramble decoy had no influence in any group. Thus, inhibition of $\mathrm{NF}-\kappa \mathrm{B}$ activation by the NF- $\kappa \mathrm{B}$ decoy induced decreased expression of Fas protein and improved cell viability in cells treated by TNF/IFN- $\alpha$. Therefore, we investigated whether cell viability was altered by enhanced Fas expression through activation of NF- $\kappa \mathrm{B}$ via TNF/IFN $-\alpha$. To clarify this issue, we used anti-Fas ligand (FasL) antibody. Cells were seeded onto six-well plates, pre-cultured for $48 \mathrm{~h}$, and treated with or without anti-FasL antibody in addition to TNF/IFN- $\alpha$ cotreatment. After $48 \mathrm{~h}$, relative viability was calculated using the 

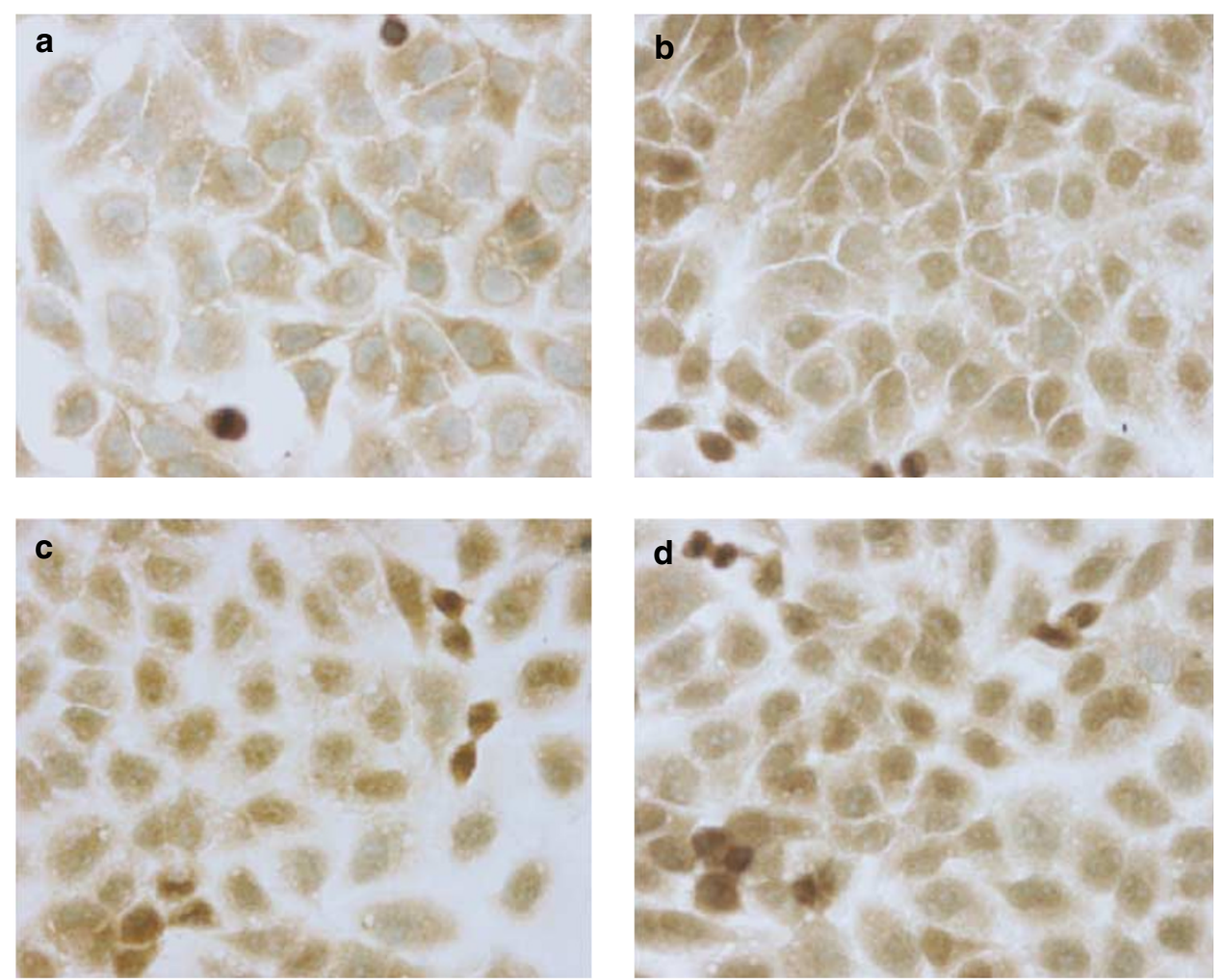

Figure 6 Nuclear translocation of NF- $\kappa$ B in RPMI4788 cells treated with TNF/IFN- $\alpha$. Combination and NF- $\kappa$ B or scramble decoy. Cells $\left(5 \times 10^{4}\right)$ were seeded onto chamber slides, precultured for $48 \mathrm{~h}$, transfected with or without NF- $\kappa \mathrm{B}$ decoy or scramble decoy for $2 \mathrm{~h}$, and then treated with TNF/IFN- $\alpha$ for 30 min. Immunohistochemical staining was performed as described in Materials \& Methods. NF- $\kappa$ B was observed mainly in the cytoplasm in cells with no treatment, whereas it transferred to the nucleus with TNF/IFN- $\alpha$ treatment, and translocation was not affected by treatment with NF- $\kappa$ B or scramble decoy. (a) No treatment, (b) TNF/IFN- $\alpha$, (c) TNF/IFN- $\alpha+N F-\kappa$ B decoy, (d) TNF/IFN- $\alpha+$ scramble decoy

trypan blue exclusion test. As shown in Figure 10a, viability in the cells treated with both TNF/IFN- $\alpha$ combination and antiFasL antibody was improved by about $30 \%$. In the next step, we examined whether recovery of viability in the cells treated with both TNF/IFN- $\alpha$ combination and anti-FasL antibody was because of a suppression of the apoptotic function of Fas. Cells were treated with or without anti-FasL antibody, in addition to treatment with TNF/IFN- $\alpha$ combination, lysed, and subjected to a caspase- 3 activity assay. Results of relative caspase- 3 activity are shown in Figure 10b. Caspase-3 activity was reduced by about $30 \%$ in cells treated with TNF/IFN- $\alpha$ combination and anti-FasL antibody in comparison to the effect of TNF/IFN- $\alpha$ cotreatment only. Therefore, we concluded that enhanced Fas expression via TNF/IFN- $\alpha$ induced apoptosis.

\section{Discussion}

TNF exerts its cytotoxic effects by inducing apoptosis in tumor cells. In addition, TNF is a cytokine with diverse biological effects, including differentiation and proliferation. Moreover, TNF activates a nuclear transcriptional factor, NF- $\kappa \mathrm{B}$, which is also activated by other stimuli, including anticancer agents and lipopolysaccharide (LPS). NF- $\kappa$ B activated by these stimuli functions as an antiapoptotic molecule. ${ }^{21-24}$ Interestingly, our results provide evidence demonstrating that activated NF- $\kappa \mathrm{B}$ induced by the cytokine crosstalk between
TNF and IFN- $\alpha$ functions in a novel proapoptotic manner, acting through enhancement of Fas expression.

Published studies have shown that combined TNF and IFN$\gamma$ treatment enhanced NF- $\kappa$ B activation in preneuronal cells and fibroblasts. ${ }^{31,33,34}$ Ouaaz et al. $^{31}$ demonstrated that cytotoxicity of TNF was enhanced by addition of IFN- $\gamma$ in mouse embryonic fibroblasts. This cytotoxicity was shown to be because of apoptosis induced by interaction of Fas and FasL, and the activation of NF- $\kappa \mathrm{B}$ induced by combined treatment with TNF and IFN- $\gamma$ was demonstrated to function in a proapoptotic manner. ${ }^{31}$ Another report showed that activated NF- $\kappa$ B exhibited opposite functions following induction by different treatments in a single cell line; NF- $\kappa \mathrm{B}$ activation induced by combined treatment with PMA and ionomycin was proapoptotic in a T-cell hybridoma cell line, whereas glucocorticoid-induced NF- $\kappa$ B was antiapoptotic in the same cells. ${ }^{35}$ TNF/IFN- $\alpha$ induced a cytotoxic response in certain tumors, ${ }^{18-20}$ and also had crosstalk interactions in immune responses. $^{36}$ We therefore investigated whether $\mathrm{NF}-\kappa \mathrm{B}$ activation induced by TNF/IFN- $\alpha$, had an antiapoptotic or proapoptotic effect. We used an NF- $\kappa$ B decoy to inhibit NF- $\kappa$ B activation to address this question. Cell viability recovered about $25 \%$ by inhibiting NF- $\kappa$ B activation after TNF/IFN- $\alpha$ cotreatment, although the cell viability was further decreased in cells treated with TNF alone. We examined caspase-3 activity to determine whether the recovery of viability in cells after inhibition of NF- $\kappa \mathrm{B}$ activation via TNF/IFN $-\alpha$ treatment by 


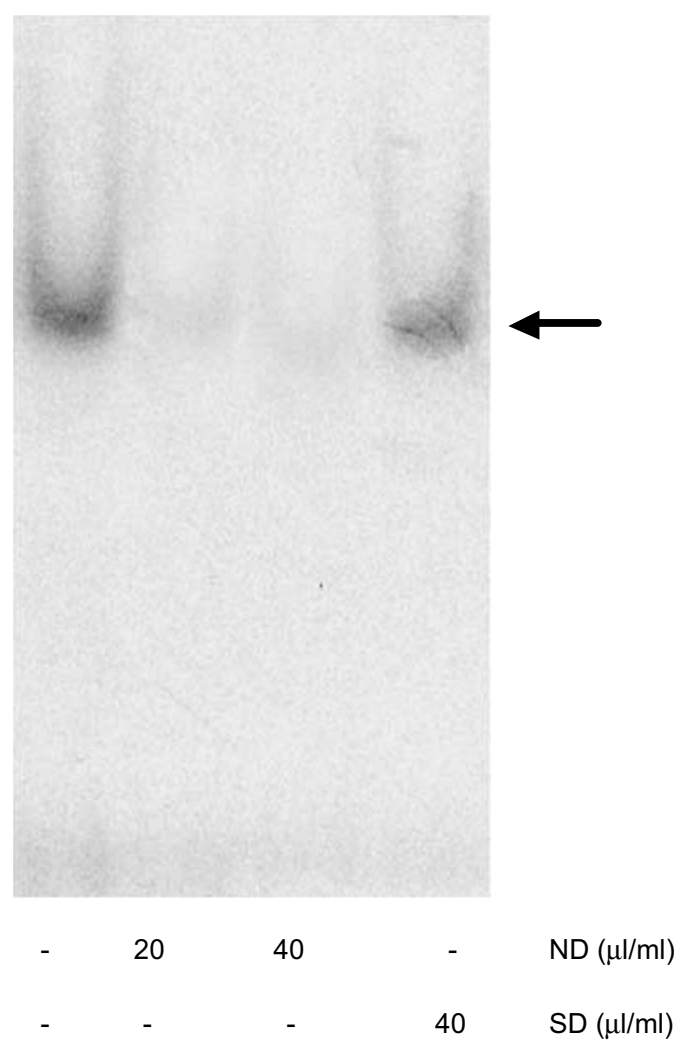

Figure 7 Inhibition of NF- $\kappa$ B activation via TNF/IFN- $\alpha$ combination with NF- $\kappa$ B decoy. Cells were transfected with either NF- $\kappa$ B decoy or scramble decoy, and then treated with TNF/IFN- $\alpha$ combination $\left(10^{4} \mathrm{HU} / \mathrm{ml}\left(10^{4} \mathrm{IU} / \mathrm{ml}\right.\right.$ of IFN- $\alpha+14 \mathrm{ng} /$ $\mathrm{ml}$ of TNF)) for $15 \mathrm{~min}$. Nuclear extracts were prepared as described in Materials and Methods. Equal amounts of nuclear extracts were subjected to EMSA with a ${ }^{32} \mathrm{P}$-labeled oligodeoxynucleotide probe containing the NF- $\kappa \mathrm{B}$ DNA binding site. Arrow indicates NF- $\kappa$ B. Similar findings were obtained in two other independent experiments

ODN decoy was because of suppression of apoptosis. Caspase- 3 activity increased more than $100 \%$ in cells treated with TNF/IFN- $\alpha$ only, in comparison to no treatment. Furthermore, addition of NF- $\kappa \mathrm{B}$ decoy inhibited this activation by about $40 \%$. These results are similar to those in cells treated with both TNF and IFN- $\gamma$, and suggest that activated NF- $\kappa$ B induced by TNF/IFN- $\alpha$ is proapoptotic in RPMI4788 cells.

We postulated that the reason why NF- $\kappa$ B activation induced by TNF/IFN- $\alpha$ was proapoptotic in RPMI4788 cells might be attributed to differences in downstream signal transduction induced by TNF/IFN- $\alpha$ or TNF- $\alpha$ alone. Previous studies demonstrated that the $\kappa \mathrm{B}$ binding site is present in the Fas promoter in T-cell lines, and that recruitment of NF- $\kappa \mathrm{B}$ to the $\kappa \mathrm{B}$ site is necessary for enhanced Fas expression. ${ }^{31,32}$ $\mathrm{NF}-\kappa \mathrm{B}$ activation is also necessary for reinforcing Fas expression in glial cells. ${ }^{37}$ Therefore, we assayed Fas expression as a downstream target of apoptotic signal transduction after NF- $\kappa \mathrm{B}$ activation. Fas expression was enhanced strongly by TNF/IFN- $\alpha$. Conversely, Fas expression was reduced by $\mathrm{NF}-\kappa \mathrm{B}$ decoy inhibition of $\mathrm{NF}-\kappa \mathrm{B}$ activation induced by TNF/IFN- $\alpha$. Furthermore, inhibition of Fas expression by anti-FasL resulted in a recovery of cell viability by about $30 \%$ as well as a decrease of caspase- 3 activity. Therefore, we propose that NF- $\kappa \mathrm{B}$ activation induced by $\mathrm{TNF} / \mathrm{IFN}-\alpha$ has a proapoptotic function, which induces
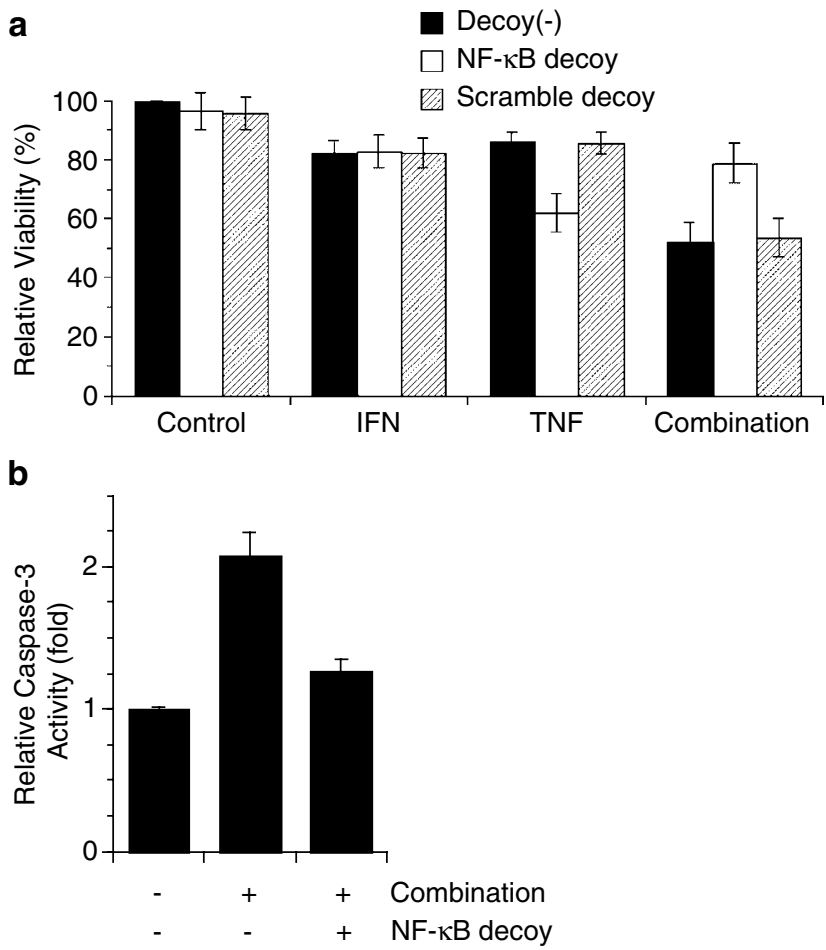

Figure 8 Inhibition of NF- $\kappa$ B activation induced by TNF/IFN- $\alpha$ decreased cytotoxicity and apoptosis. (a) Cells were seeded onto six-well plates at $10^{5}$ cells/ well and precultured for $48 \mathrm{~h}$. They were then incubated with either NF- $\kappa \mathrm{B}$ decoy or scramble decoy (control) for $2 \mathrm{~h}$ prior to treatment with or without each cytokine (IFN- $\alpha 10^{4} \mathrm{IU} / \mathrm{ml}$, TNF $14 \mathrm{ng} / \mathrm{ml}$, combination $10^{4} \mathrm{HU} / \mathrm{ml}\left(10^{4} \mathrm{IU} / \mathrm{ml}\right.$ of IFN$\alpha+14 \mathrm{ng} / \mathrm{ml}$ of TNF)) for $48 \mathrm{~h}$. After treatment for $48 \mathrm{~h}$, cells were collected, and viable cell numbers were counted by trypan blue exclusion. Relative viability was calculated as follows: relative viability $(\%)=$ (viable cell numbers in treated group/ viable cell numbers in control group) $\times 100$. Data from four independent experiments involving triplicate assays were averaged and presented as mean + S.D. (b) Cells were seeded onto six-well plates at $10^{5}$ cells/well and pre-cultured for $48 \mathrm{~h}$. After transfecting with or without NF- $\kappa \mathrm{B}$ decoy, cells were treated with or without TNF/IFN- $\alpha$ combination $\left(10^{4} \mathrm{HU} / \mathrm{ml}\left(10^{4} \mathrm{IU} / \mathrm{ml}\right.\right.$ of IFN- $\alpha+14 \mathrm{ng} / \mathrm{ml}$ of TNF)), and subjected to caspase-3 activity assay as described in Materials and Methods. Relative caspase-3 activity was calculated as follows: relative caspase3 activity $=$ caspase -3 activity of cells treated with TNF/IFN- $\alpha$ combination or caspase- 3 activity of cells treated with both TNF/IFN- $\alpha$ combination and NF- $\kappa$ B decoy/caspase- 3 activity of cells treated without TNF/IFN- $\alpha$ and NF- $\kappa$ B decoy. Data from independent experiments involving triplicate assays were averaged and presented as mean \pm S.D

apoptosis via enhancement of Fas expression in tumor cells.

Although the mechanism of enhancement of Fas expression by $\mathrm{TNF} / \mathrm{IFN}-\alpha$ is not yet clear, we can speculate on several factors. Functional analysis using reporter constructs and transient transfections identified a silencer activity residing in the promoter of the Fas gene. ${ }^{38}$ Yin Yang-1 (YY1) is a DNAbinding zinc-finger transcription factor functioning as an activator, a repressor, and an initiator of transcription. ${ }^{39}$ Nitric oxide (NO) has been implicated in transcriptional control, and serves as an intracellular second messenger to modify gene expression. In a recent study, IFN- $\gamma$ was reported to increase the generation of $\mathrm{NO}$ by induction of inducible nitric-oxide synthase (iNOS), which sensitized ovarian tumor cells to Fasinduced apoptosis. ${ }^{40}$ Garban et al. then showed that Fasinduced apoptosis via NO was because of upregulation of Fas receptor expression on AD10 ovarian cancer cells via specific 


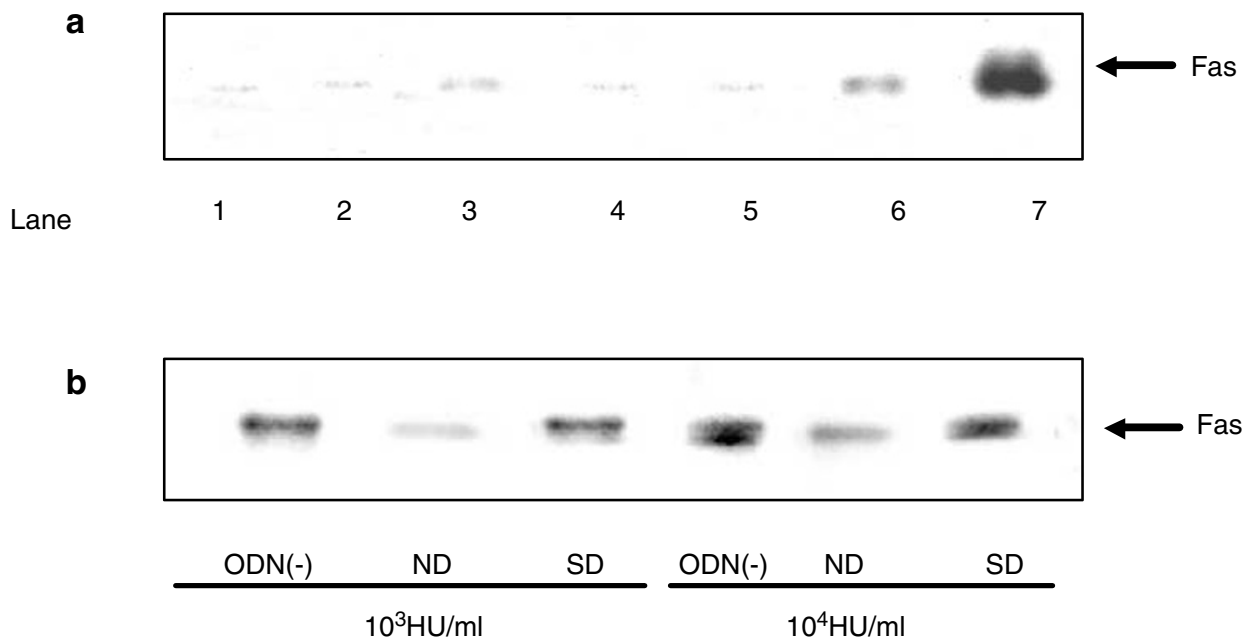

Figure 9 TNF/IFN- $\alpha$ strongly upregulated Fas expression. (a) Cells were treated with or without each cytokine for $48 \mathrm{~h}$, and equivalent amounts of whole-cell extracts were analyzed by Western blot using anti-Fas antibody. Arrows indicate Fas. Lanes 1 , control; 2, IFN- $\alpha 10^{3} \mathrm{IU} / \mathrm{ml} ; 3$, IFN- $\alpha 10^{4} \mathrm{IU} / \mathrm{ml} ; 4$, TNF $1.4 \mathrm{ng} / \mathrm{ml} ; 5$, TNF $14 \mathrm{ng} / \mathrm{ml}$; 6, TNF/IFN- $\alpha$ combination $10^{3} \mathrm{HU} / \mathrm{ml}\left(10^{3} \mathrm{IU} / \mathrm{ml}\right.$ of IFN- $\alpha+1.4 \mathrm{ng} / \mathrm{ml}$ of TNF); 7 , TNF/IFN- $\alpha$ combination $10^{4} \mathrm{HU} / \mathrm{ml}\left(10^{4} \mathrm{IU} / \mathrm{ml}\right.$ of IFN- $\alpha+14 \mathrm{ng} / \mathrm{ml}$ of TNF). (b) After transfection with NF- $\kappa$ B or scramble decoy, cells were treated with TNF/IFN- $\alpha\left(10^{3} \mathrm{HU} / \mathrm{ml}, 10^{4} \mathrm{HU} / \mathrm{ml}\right)$ for $48 \mathrm{~h}$, and then Western blot analysis was performed using antiFas antibody. Arrows indicate Fas protein. ODN (-), without decoy; ND, with NF- $\kappa$ B decoy; SD, with scramble decoy. Similar findings were obtained in two other independent experiments

inactivation of the transcriptional repressor YY1 DNA-binding activity in the silencer region of the Fas promoter. Thus, NO promoted the removal of YY1 repressor activity, and freed the Fas promoter to increase transcriptional activation of the Fas gene. ${ }^{41}$ In another recent study, exposure of AD 10 cells to IFN$\gamma$ sensitized the tumor cells to TNF-mediated cytotoxicity in a dose-dependent manner, and this sensitization was significantly decreased in the presence of iNOS inhibitor. ${ }^{42}$ Conversely, NF- $\kappa$ B has been shown to be an important regulator of iNOS. ${ }^{42}$ Taken together, these reports and our results lead us to propose that IFN $-\alpha$ has synergistic activity with NF- $\kappa$ B on Fas expression through production of NO, which releases suppressor elements in the Fas promoter, and thus activates its transcription.

In summary, TNF/IFN- $\alpha$ combined treatment induced stronger and earlier NF- $\kappa$ B activation compared with TNF treatment alone. This activation was initiated by prolonged $I_{\kappa} \mathrm{B} \alpha$ degradation, and functioned in a proapoptotic manner by enhancement of Fas expression. Our observations provide the first evidence in carcinoma cells indicating that TNFinduced NF- $\kappa$ B activation, which has an antiapoptotic function, may be modified to a proapoptotic function by cytokine crosstalk between TNF and IFN- $\alpha$. Such actions might be of clinicopharmacological value, where apoptosis of tumor cells could be efficiently induced by TNF/IFN- $\alpha$ and FasL, or upregulators of FasL in combination might become a clinically applicable new strategy in cancer therapy.

\section{Materials and Methods}

\section{Cell culture and cytokine treatments}

Human colon adenocarcinoma cells, RPMI4788, were kindly provided by the Roswell Park Memorial Institute (Buffalo, NY, USA). Cells were maintained in RPMl1640 medium (Nissui Seiyaku Co., Tokyo, Japan) supplemented with $10 \%$ fetal calf serum (FCS), $25 \mathrm{mM} \mathrm{HEPES}, 100 \mathrm{U} / \mathrm{ml}$ penicillin, and $100 \mathrm{mg} / \mathrm{ml}$ streptomycin in a humidified incubator containing $5 \% \mathrm{CO}_{2}$, and used for in vitro assays. TNF and IFN- $\alpha$, produced from $\mathrm{HVJ}$ stimulated B-cell acute lymphatic leukemia line (BALL-1) cells and purified to homogeneity as judged by SDS-polyacrylamide gel electrophoresis, were kindly supplied by Hayashibara Biochemical Laboratories, Inc. (Okayama, Japan). ${ }^{43}$

The molecular weight of TNF is $17000 \mathrm{Da}$ and the specific activity is $3 \times 10^{6} \mathrm{JRU} / \mathrm{mg}$ protein. Our standard was titrated against a Japanese Reference (J-PS5KO 1, National Institute of Health, Tokyo, Japan). The titers of IFN- $\alpha$ were determined in a cytopathic effect inhibition assay using human $\mathrm{FL}$ cells challenged with sindbis virus, and standardized against an international reference preparation of human IFN- $\alpha$ (Ga23-901-532). ${ }^{44,45}$

Tumor cells were treated with or without cytokines as follows. control group: complete medium without cytokines; IFN- $\alpha$ group: complete medium with IFN- $\alpha\left(10^{2}-10^{5} \mathrm{IU} / \mathrm{ml}\right)$; TNF group: complete medium with TNF $(0.14-140 \mathrm{ng} / \mathrm{ml})$; combination group: complete medium with IFN$\alpha+T N F$. The combination group was prepared as follows. $10^{2} \mathrm{HU} / \mathrm{ml}$ : $10^{2} \mathrm{IU} / \mathrm{ml}$ of IFN- $\alpha+0.14 \mathrm{ng} / \mathrm{ml}$ of TNF; $10^{3} \mathrm{HU} / \mathrm{ml}: 10^{3} \mathrm{IU} / \mathrm{ml}$ of IFN$\alpha+1.4 \mathrm{ng} / \mathrm{ml}$ of TNF; $10^{4} \mathrm{HU} / \mathrm{ml}: 10^{4} \mathrm{IU} / \mathrm{ml}$ of IFN- $\alpha+14 \mathrm{ng} / \mathrm{ml}$ of TNF; and $10^{5} \mathrm{HU} / \mathrm{ml}: 10^{5} \mathrm{IU} / \mathrm{ml}$ of IFN- $\alpha+140 \mathrm{ng} / \mathrm{ml}$ of TNF.

\section{Cell viability}

Cells were seeded onto six-well plates at $10^{5}$ cells/well, and precultured at $37^{\circ} \mathrm{C}$ for $48 \mathrm{~h}$. The medium was then removed by aspiration and replaced with a fresh culture medium containing each cytokine. Cells were treated for 24,48 , or $72 \mathrm{~h}$ and then collected by trypsinization. Viable cell numbers were simultaneously counted by trypan blue exclusion. Relative viability was calculated as follows: relative viability $(\%)=$ (viable cell numbers in treated group/viable cell numbers in control group) $\times 100$.

\section{Immunohistochemical analysis}

Cells were seeded onto chamber slides at $5 \times 10^{4}$ cells/slide. After preculture for $48 \mathrm{~h}$, cells were treated with or without each cytokine as indicated. Treated cells were washed once with cold phosphate-buffered 
a

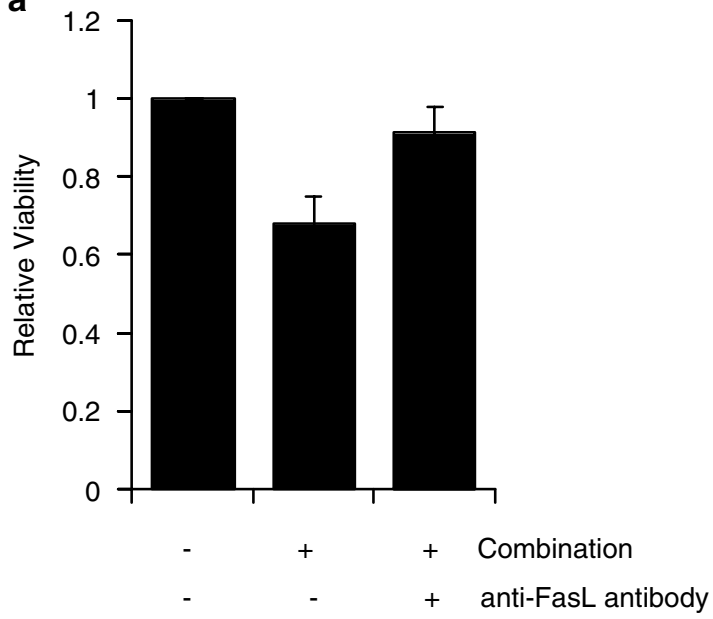

b

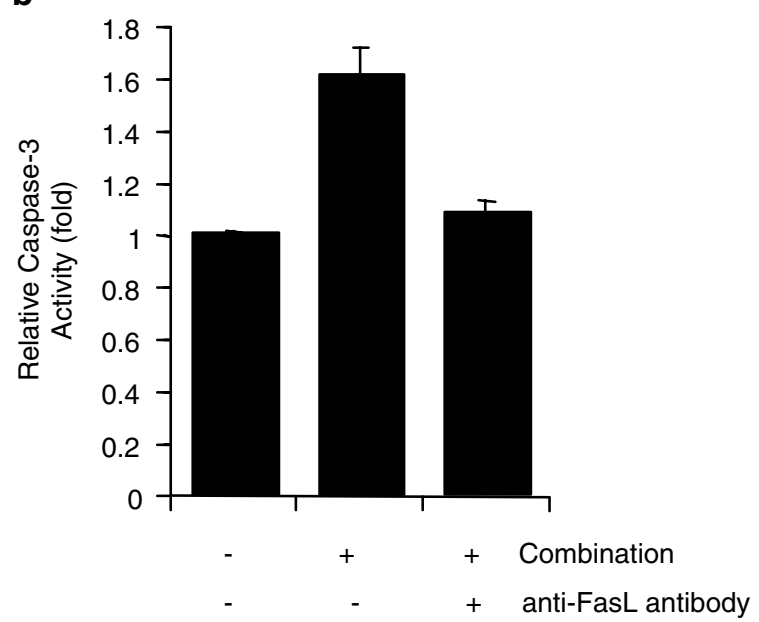

Figure 10 Anti-FasL antibody recovered cell viability and reduced apoptosis in RPMI 4788 cells treated with TNF/IFN- $\alpha$ combination. Cells were seeded onto sixwell plates at $10^{5}$ cells/well, precultured for $48 \mathrm{~h}$, and treated with TNF/IFN- $\alpha$ combination and anti-FasL antibody or TNF/IFN- $\alpha$ combination only. (a) Cells were harvested $48 \mathrm{~h}$ after treatment, and viable cell numbers were counted by trypan blue exclusion. Relative viability was calculated as follows: relative viability $=$ viable cell numbers treated with $\mathrm{TNF} / \mathrm{FN}-\alpha$ combination or viable cell numbers treated with both TNF/IFN- $\alpha$ combination and anti-Fas $L$ antibody/viable cell numbers treated without TNF/IFN- $\alpha$ and anti-FasL antibody. (b) Cells were harvested $48 \mathrm{~h}$ after treatment, lysed, and subjected to caspase-3 activity assay as described in Materials and Methods. Relative caspase-3 activity was calculated as follows: relative caspase- 3 activity=caspase- 3 activity of cells treated with TNF/IFN- $\alpha$ combination or caspase-3 activity of cells treated with both TNF/IFN- $\alpha$ combination and anti-FasL antibody/caspase- 3 activity of cells treated without TNF/IFN- $\alpha$ and anti-FasL antibody. Data from independent experiments involving triplicate assays were averaged and presented as mean \pm S.D

saline (PBS), and then fixed in cold $20 \%$ formaldehyde for $10 \mathrm{~min}$. Immunohistochemical staining was performed using a Histofine SAB PO kit (Nichirei, Tokyo, Japan). Briefly, endogenous peroxidase was blocked by incubating the fixed cells in $3 \% \mathrm{H}_{2} \mathrm{O}_{2}$ in methanol for $15 \mathrm{~min}$. After blocking of nonspecific reactivity with normal goat serum for $10 \mathrm{~min}$ at room temperature, cells were incubated overnight at $4^{\circ} \mathrm{C}$ with the primary antibody. Identification of the distribution of primary antibody was achieved by subsequent application of a biotinylated antiprimary antibody and streptavidin-peroxidase. Immunostaining was detected using $\mathrm{DAB} / \mathrm{H}_{2} \mathrm{O}_{2}$ solution (Histofine DAB substrate kit; Nichirei), and cells were counterstained with methyl green. Nuclear translocation of NF- $\kappa$ B was considered positive if nuclear staining was predominant over cytoplasmic staining or if only nuclear staining was detected. The percentage of positively stained nuclei was semiquantitatively evaluated by counting at least 2000 cells/ slide as follows: Ratio of nuclei positively stained cells $(\%)=$ (number of nuclei positively stained / total cells counted) $\times 100$.

\section{Preparation of whole-cell extracts}

Cells were washed with PBS, harvested, pelleted, and resuspended in lysis buffer (20 mM Tris- $\mathrm{HCl}$ [pH 7.6], $150 \mathrm{mM} \mathrm{NaCl}, 1 \mathrm{mM} \mathrm{CaCl}_{2}, 1 \mathrm{mM}$ $\mathrm{MgCl}_{2}, 1 \% \mathrm{NP}-40,10 \%$ glycerol, $1 \mathrm{mM}$ dithiothreitol [DTT], $20 \mathrm{mg} / \mathrm{ml}$ aprotinin, $20 \mathrm{mM}$ leupeptin, and $1 \mathrm{mM}$ phenylmethylsulfonylfluoride (PMSF)). After $30 \mathrm{~min}$ on ice, the lysates were resuspended, and centrifuged at 15000 r.p.m. at $4^{\circ} \mathrm{C}$ for $60 \mathrm{~min}$. The supernatants were used as whole-cell extracts. Protein concentrations were determined using the Bio-Rad protein determination method (Bio-Rad, Hercules, CA, USA).

\section{Preparation of nuclear extracts}

Cells were washed with PBS, harvested, pelleted, and resuspended in lysis buffer (10 mM Tris-HCl (pH 8.0), 60 mM KCl, 1 mM EDTA, 1 mM DTT, $0.2 \mathrm{mM}$ PMSF, $20 \mathrm{mg} / \mathrm{ml}$ aprotinin, $20 \mathrm{mM}$ leupeptin, and $0.5 \% \mathrm{NP}-40$ ). After $5 \mathrm{~min}$ on ice, the lysates were centrifuged at 2500 r.p.m. at $4^{\circ} \mathrm{C}$ for $5 \mathrm{~min}$. The supernatant was removed and the pellet was briefly washed in lysis buffer free of NP-40, and centrifuged at 1200 r.p.m. The pellet was resuspended in an equal volume of nuclear extract buffer $(20 \mathrm{mM}$ Tris- $\mathrm{HCl}$ (pH 8.0), $420 \mathrm{mM} \mathrm{NaCl}, 1.5 \mathrm{mM} \mathrm{MgCl}_{2}, 0.2 \mathrm{mM}$ EDTA, and 25\% glycerol). After a 10 -min incubation at $4{ }^{\circ} \mathrm{C}$, the suspension was briefly vortexed and centrifuged at 14000 r.p.m. for $5 \mathrm{~min}$. The supernatant was removed, and used as a nuclear extract. Protein concentrations were determined by the same method as described for whole-cell extracts.

\section{Western blot analysis}

Equal amounts of proteins were electrophoresed under reducing conditions on $7.5-12 \%$ polyacrylamide gels. Proteins were electrophoretically transferred to hybond-polyvinylidene difluoride (PVDF) transfer membranes and incubated with primary antibody followed by peroxidaselinked secondary antibody. An Amersham ECL chemiluminescent Western system (Amersham Pharmacia Biotech, Tokyo, Japan) was used to detect secondary probes.

\section{Antibodies}

Monoclonal mouse anti-PARP antibody (BIOMOL Inc., Plymouth Meeting, PA, USA) was used for assay of PARP cleavage. Polyclonal rabbit antiNF- $\kappa$ B antibody (Santa Cruz Biotech, Santa Cruz, CA, USA) and monoclonal mouse anti-Fas antibody (Santa Cruz) were used for detection of nuclear translocation of NF- $\kappa \mathrm{B}$ and Fas protein expression, respectively. Whole-cell extract of human $\mathrm{HL}-60$ leukemia cells, induced to undergo apoptosis by etoposide (BIOMOL Inc.), was used as a positive control for PARP cleavage. Anti-human FasL antibody was obtained from MBL Co. Ltd. Nagoya, Japan, and used at a concentration of $0.1 \mathrm{mg} / \mathrm{ml}$ for neutralizing the cytotoxic activity of Fas.

\section{Electrophoretic mobility shift assay (EMSA)}

EMSA was performed according to the protocol recommended by the supplier (GelShift ${ }^{\mathrm{TM}}$ assay Kit; Stratagene, La Jolla, CA, USA). A doublestranded oligonucleotide containing the NF- $\mathrm{KB}$ binding site (5'-GAT CGA 
GGG GAC TTT CCC TAG C-3') was end-labeled with $\gamma^{32}{ }^{32}$-ATP and used as a probe. The binding reaction of $5 \mathrm{~g}$ nuclear extract and ${ }^{32} \mathrm{P}$-labeled DNA was performed in incubation buffer on ice for $30 \mathrm{~min}$. The resulting complexes were resolved on polyacrylamide gels. Gels were dried and DNA-protein complexes were visualized by autoradiography.

\section{Decoy oligodeoxynucleotide sequences}

Sequences of phosphorothioate-labeled ODNs used were as follows. NF$\kappa \mathrm{B}$ decoy ODN (consensus sequences are underlined): $5^{\prime}$-CCTTGAAGGGATTTCCCTCC-3', 3'-GGAACTTCCCTAAAGGGAGG-5'.

Scramble decoy ODN (as negative control): $5^{\prime}$-TTGCCGTACCTGACTTAGCC-3', 3'-AACGGCATGGACTGAATCGG-5'

\section{Transfection of NF- $\kappa$ B decoy in vitro}

HVJ-liposome complexes containing ODN at $3 \mu \mathrm{M}$ were kindly provided by Dr. Y Kaneda (Division of Gene Therapy Science, Osaka University Medical School, Osaka, Japan). Cells were seeded onto six-well plates at $10^{5} \mathrm{cells} /$ well and precultured at $37^{\circ} \mathrm{C}$ for $48 \mathrm{~h}$. Next, the medium was replaced with fresh medium containing $20 \mu \mathrm{HVJ}$-liposome complexes and reincubated for $2 \mathrm{~h}$ to transfect decoy ODNs to tumor cells. After transfection of decoy ODNs, cells were treated with cytokines and cell viability was examined as described above.

\section{Assay for caspase-3 activity}

Caspase-3 activity assay was performed according to the manufacturer's protocol (Caspase-3/CPP32 fluorometric protease assay kit; MBL, Nagoya, Japan). Briefly, cells were seeded onto six-well plates at $10^{5} \mathrm{cells} /$ well and precultured at $37^{\circ} \mathrm{C}$ for $48 \mathrm{~h}$. Cells were then treated with or without cytokines for $48 \mathrm{~h}$, washed once with PBS, and collected by scraping. Treated cells were suspended in cell lysis buffer for $40 \mathrm{~min}$ at $4^{\circ} \mathrm{C}$ and protein concentrations were determined using the Bio-Rad protein determination method (Bio-Rad). Protein $(25 \mu \mathrm{g})$ in $50 \mu \mathrm{l}$ of cell lysis buffer was added to $50 \mu \mathrm{l}$ of reaction buffer and $5 \mu \mathrm{l}$ of the $1-\mathrm{mM}$ DEVD-AFC substrate and incubated at $37^{\circ} \mathrm{C}$ for $1 \mathrm{~h}$. Samples were read in a fluorometer (Spectrofluorophotometer RF-1500; SHIMADZU, Kyoto, Japan) with a 390-nm excitation filter and 510-nm emission filter.

\section{Acknowledgements}

We thank Tohru Tanida and Kyoko Nasu for their technical support. This work was supported in part by Grants-in-Aid from the Ministry of Education, Science, Sports and Culture of the Japanese Government 12671228 (to $\mathrm{MH}$ ).

\section{References}

1. Carswell EA, Old LJ, Kassel RL, Green S, Fiore N and Williamson B (1975) An endotoxin-induced serum factor that causes necrosis of tumors. Proc. Natl. Acad. Sci. USA 72: 3666-3670

2. Fiers W (1991) Tumor necrosis factor, characterization at the molecular, cellular and in vivo level. FEBS Lett. 285: 199-212

3. Loetscher H, Pan Y-CE, Lahm H-W, Gentz R, Brockhaus M, Tabuchi H and Lesslauer W (1990) Molecular cloning and expression of the human $55 \mathrm{kD}$ tumor necrosis factor receptor. Cell 61: 351-359

4. Schall TJ, Lewis M, Koller KJ, Lee A, Rice GC, Wong GHW, Gatanaga T, Granger GA, Lentz R, Raab H, Kohr WJ and Goeddel DV (1990) Molecular cloning and expression of a receptor for human tumor necrosis factor. Cell 61 : 361-370

5. Hsu H, Shu H-B, Pan M-G and Goeddel DV (1996) TRADD-TRAF2 and TRADD-FADD interactions define two distinct TNF receptor 1 signal transduction pathways. Cell 84: 299-308

6. Boldin MP, Goncharov TM, Goltsev YV and Wallach D (1996) Involvement of $\mathrm{MACH}$, a novel MORT1/FADD-interesting protease, in Fas/APO-1-and TNF receptor-induced cell death. Cell 85:803-815

7. Muzio M, Chinnaiyan AM, Kischkel FC, O'Rourke K, Shevchenko A, Ni J, Scaffidi C, Bretz JD, Zhang M, Gentz R, Mann M, Krammer PH, Peter ME and Dixit VM (1996) FLICE, a novel FADD-homologous ICE/CED-3-like protease, is recruited to the CD95 (Fas/APO-1) death-inducing signaling complex. Cell 85: 817-827

8. Malinin NL, Boldin MP, Kovalenko AV and Wallach D (1997) MAP3K-related kinase involved in NF- $\kappa$ B induction by TNF, CD95 and IL-1. Nature 385: 540544

9. Didonato JA, Hayakawa M, Rothwarf DM, Zandi E and Karin M (1997) A cytokine-responsive $\mathrm{I} \kappa \mathrm{B}$ kinase that activates the transcription factor NF- $\kappa \mathrm{B}$. Nature 388: 548-554

10. Regnier CH, Song HY, Gao X, Goeddel DV, Cao Z and Rothe M (1997) Identification and characterization of an I $\kappa$ B kinase. Cell 90: 373-383

11. Zandi E, Rothwarf DM, Delhase M, Hayakawa M and Karin M (1997) The $I_{\kappa} B$ kinase complex (IKK) contains two kinase subunits, IKK $\alpha$ and IKK $\beta$, necessary for $\mathrm{I}_{\kappa} \mathrm{B}$ phosphorylation and NF- $\kappa \mathrm{B}$ activation. Cell $91: 243-252$

12. Baeuerle $P A$ and Baltimore $D(1988) I \kappa B$ : a specific inhibitor of the $N F-\kappa B$ transcription factor. Science 242: $540-546$

13. Brown K, Gerstberger S, Carlson L, Franzoso G and Siebenlist U (1995) Control of $\mathrm{I}_{\kappa} \mathrm{B}-\alpha$ proteolysis by site-specific, signal-induced phosphorylation. Science 267: 1485-1488

14. Traenckner EB-M, Pahl HL, Henkel T, Schmidt KN, Wilk S and Baeuerle PA (1995) Phosphorylation of human IkB- $\alpha$ on serines 32 and 36 controls $\mid \kappa B-\alpha$ proteolysis and NF- $\kappa$ B activation in response to diverse stimuli. EMBO J. 14: 2876- 2883

15. Didonato J, Mercurio F, Rosette $\mathrm{C}$, Wu-LiJ, Suyang $\mathrm{H}$, Ghosh $\mathrm{S}$ and Karin $\mathrm{M}$ (1996) Mapping of the inducible $\mid \kappa B$ phosphorylation sites that signal its ubiquitination and degradation. Mol Cell Biol. 16: 1295-1304

16. Whiteside ST, Ernst MK, LeBail O, Laurent-Winter C, Rice N and Israel A (1995) $\mathrm{N}$ - and C-terminal sequences control degradation of MAD3//KB $\alpha$ in response to inducers of NF- $\kappa$ B activity. Mol Cell Biol. 15: 5339-5345

17. Lin L, DeMartino GN and Greene WC (1998) Cotranslational biogenesis of NF$\kappa \mathrm{B}$ p50 by the $26 \mathrm{~S}$ proteasome. Cell $92: 819-828$

18. Williamson BD, Carswell EA, Rubin BY, Prendergast JS and Old Lj (1983) Human tumor necrosis factor produced by human B-cell lines: synergistic cytotoxic interaction with human interferon. Proc. Natl. Acad. Sci. USA 80: 5397-5540

19. Naomoto $Y$, Tanaka N, Fuchimoto S and Orita K (1987) In vitro synergistic effects of natural human tumor necrosis factor and natural human interferon- $\alpha$. Jpn. J. Cancer Res. 78: 87-92

20. Muro M, Naomoto $Y$ and Orita K (1991) Mechanism of the combined antitumor effect of natural human tumor necrosis factor- $\alpha$ and natural human interferon- $\alpha$ on cell cycle progression. Jpn. J. Cancer Res. 82: 118-126

21. Beg AA and Baltimore D (1996) An essential role for NF-kappaB in preventing TNF- $\alpha$-induced cell death. Science 274: 782-784

22. Wang C-Y, Mayo MW and BaldwinJr. AS (1996) TNF- and cancer therapyinduced apoptosis: potentiation by inhibition of NF- $\kappa$ B. Science 274: 784-787

23. Van Antwerp DJ, Martin SJ, Kafri T, Green DR and Verma IM (1996) Suppression of TNF- $\alpha$-induced apoptosis by NF- $\kappa$ B. Science 274 : 787-790

24. Sugiyama H, Savill JS, Kitamura M, Zhao L and Stylianou F (1999) Selective sensitization to tumor necrosis factor- $\alpha$-induced apoptosis by blockade of NF$\kappa \mathrm{B}$ in primary glomerular mesangial cells. J. Biol. Chem. 274: 19532-19537

25. Otsuka G, Nagaya T, Saito K, Mizuno M, Yoshida J and Seo H (1999) Inhibition of nuclear factor- $\kappa \mathrm{B}$ confers sensitivity to tumor necrosis factor- $\alpha$ by impairment of cell cycle progression in human glioma cells. Cancer Res. 59: 4446-4452

26. Morishita $R$, Gibbons $G H$, Horiuchi $M$, Ellison KE, Nakajima $M$, Zhang L, Kaneda Y, Ogihara T and Dzau AJ (1995) A gene therapy strategy using a transcription factor decoy of the E2F binding site inhibits smooth muscle proliferation in vivo. Proc. Natl. Acad. Sci. USA 92: 5855-5859 
27. Morishita R, Sugimoto T, Aoki M, Kida I, Tomita N, Moriguchi A, Maeda K, Sawa $Y$, Kaneda $Y$, Higaki J and Ogihara T (1997) In vivo transfection of cis element 'decoy' against nuclear factor- $\kappa \mathrm{B}$ binding site prevents myocardial infarction. Nat. Med. 3: 894-899

28. Hosoya T, Takeuchi H, Kanesaka Y, Yamakawa H, Miyano-Kurosaki N, Takai K, Yamamoto N and Takaku H (1999) Sequence-specific inhibition of a transcription factor by circular dumbbell DNA oligonucleotides. FEBS Lett. 461: $136-140$

29. Kaneda Y, Uchida T, Kim J, Ishiura M and Okada $Y$ (1987) The improved efficient method for introducing macromolecules into cells using HVJ (Sendai Virus) liposomes with gangliosides. Exp Cell Res. 173: 56-69

30. Saeki Y, Matsumoto N, Nakano Y, Mori M, Awai K and Kaneda Y (1997) Development and characterization of cationic liposomes conjugated with HVJ (Sendai Virus): reciprocal effect of cationic lipid for in vitro and in vivo. Gene transfer. Hum. Gene Therapy 8: 2133-2141

31. Ouaaz F, Li M and Beg AA (1999) A critical role for the Rel A subunit of nuclear factor- $\kappa B$ in regulation of multiple immune-response genes and in Fas-induced cell death. J. Exp. Med. 189: 999-1004

32. Chan H, Bartos DP and Owen-Schaub LB (1999) Activation-dependent transcriptional regulation of the human Fas promoter requires NF- $\kappa$ B p50-p65 recruitment. Mol Cell Biol. 19: 2098-2108

33. Cheshire JL, Williams BRG and BaldwinJr AS (1999) Involvement of doublestranded RNA-activated protein kinase in the synergistic activation of nuclear factor- $\kappa \mathrm{B}$ by tumor necrosis factor- $\alpha$ and $\gamma$-interferon in preneuronal cells. $J$. Biol. Chem. 274: 4801-4806

34. Zamanian-Daryoush M, Mogensen TH, Didonato JA and Williams BRG (2000) $\mathrm{NF}-\kappa \mathrm{B}$ activation by double-stranded-RNA-activated protein kinase (PKR) is mediated through NF- $\kappa$ B-inducing kinase and $I_{\kappa} B$ kinase. Mol Cell Biol. 20: $1278-1290$

35. Lin B, Williams-Skipp C, Tao Y, Schleicher MS, Cano LL, Duke RC and Scheinman RI (1999) NF- $\kappa$ B functions as both a proapoptotic and antiapoptotic regulatory factor within a single cell type. Cell Death Differ. 6: $570-582$
36. McIntosh JK, Mule JJ, Krosnick JA and Rosenberg, SA (1989) Combination cytokine immunotherapy with tumor necrosis factor- $\alpha$, interleukin 2 , and $\alpha$ interferon and its synergistic antitumor effects in mice. Cancer Res. 49: 14081414

37. Lee SJ, Zhou T, Choi C, Wang Z and Benveniste EN (2000) Differential regulation and function of Fas expression on glial cells. J. Immunol. 164: 12771285

38. Rudert F, Visser E, Forbes L, Lindridge, Wang $Y$ and Watson J (1995) Identification of a silencer, enhancer and basal promoter region in the human CD95 (Fas/APO-1) gene. DNA Cell Biol. 14:931-937

39. Shrivastava A and Calame CK (1994) An analysis of genes regulated by the multi-functional transcriptional regulator Yin Yang-1. Nucleic Acids Res. 22:5151-5155

40. Garban HJ and Bonavida B (1999) Nitric oxide sensitizes ovarian tumor cells to Fas-induced apoptosis. Gynecol Oncol. 73:257-264

41. Garban HJ and Bonavida B (2001) Nitric oxide inhibits the transcription repressor Yin-Yang 1 binding activity at the silencer region of the Fas promoter: a pivotal role for nitric oxide in the up-regulation of Fas gene expression in human tumor cells. J. Immunol. 167:75-81

42. Garban $\mathrm{HJ}$ and Bonavida $\mathrm{B}$ (2001) Nitric oxide disrupts $\mathrm{H}_{2} \mathrm{O}_{2}$ dependent activation of nuclear factor $\kappa \mathrm{B}$. Role in sensitization of human tumor cells to tumor necrosis factor-induced cytotoxicity. J. Biol. Chem. 276:8918-8923

43. Fukuda S, Ando S, Sanou O, Taniai M, Fujii M, Masaki N, Nakamura K, Ando O, Torigoe K, Sugimoto T and Kurimoto M (1988) Simultaneous production of natural human tumor necrosis factor- $\alpha,-\beta$ and interferon- $\alpha$ from BALL-1 cells stimulated by HVJ. Lymphokine Res. 7: 175-185

44. Fukuda $S$, Yamane $Y$, Kouguchi $M$, Ando $S$, Sato $Y$ and Kurimoto $M$ (1987) Purification and characterization of natural human tumor necrosis factor from HVJ stimulated BALL-1 cells. Chem Express 2: 101-104

45. Ando S, Sanou O, Fujii M, Sato $Y$ and Kurimoto M (1987) Large scale production and characterization of natural human interferon- $\alpha$ from HVJstimulated BALL-1 cells. Chem Express 2: 45-48 